\title{
Entrepreneurship as Facilitator for Sustainable Development? Editorial for the Special Issue "Advances in Sustainable Entrepreneurship"
}

\author{
Jacob Hörisch
}

Department for Business Management, Faculty of Human Sciences and Social Sciences, Alanus University, Villestrasse 3, Alfter (Bonn) 53347, Germany; jacob.hoerisch@alanus.edu

Received: 16 March 2016; Accepted: 16 March 2016; Published: 18 March 2016

Keywords: sustainable entrepreneurship; sustainability transitions; sustainable development; business sustainability; research needs; research gaps

\section{Why Is Sustainable Entrepreneurship Relevant?}

"... the function of entrepreneurs is to reform or revolutionize the pattern of production by exploiting an invention or, more generally, an untried technological possibility for producing a new commodity or producing an old one in a new way, by opening up a new source of supply of materials or a new outlet for products, by reorganizing an industry and so on."

(Schumpeter ([1], p. 132))

In his quote from the 1940s, Joseph Schumpeter highlights the enormous transformative potential of entrepreneurship. Three quarters of a century later, this transformative potential is increasingly being discussed against the background of sustainable development, e.g., [2-4]. However, most research on business sustainability still focuses on corporate sustainability, even though previous research suggests that large differences with regard to business sustainability exist, depending on company size [5] and that not only established corporations, but also entrepreneurs have a decisive role to play in sustainable development [2].

Consequently, Hockerts and Wüstenhagen ([2], p. 482), define "sustainable entrepreneurship as the discovery and exploitation of economic opportunities through the generation of market disequilibria that initiate the transformation of a sector towards an environmentally and socially more sustainable state". This special issue builds on Hockerts and Wüstenhagen's [2] definition, as it emphasizes the role of sustainable entrepreneurship in sustainable development by stressing the transformative function of the concept, as well as the requirements for entrepreneurship to fulfill this function.

\section{Articles in this Special Issue}

In their article entitled "The Dilemma of Incumbents in Sustainability Transitions: A Narrative Approach", Karoline Augenstein and Alexandra Palzkill [6] pick up the debate on potential contributions of different business actors to sustainability transitions. They analyze in how far incumbents, i.e., established corporations, can act as sustainable entrepreneurs by linking the principle of sufficiency to successful business strategies. The authors thereby develop a conceptual approach which combines insights from sustainable entrepreneurship with insights from management, sociology and transition research. Augenstein and Palzkill focus on narratives of incumbents and on how these narratives can enable or hinder incumbents from incorporating sufficiency to their strategies and on how narratives can serve as a translation mechanism in situations where tensions emerge between corporate strategies and unexpected societal trends. 
Jacob Hörisch's [7] article "The Role of Sustainable Entrepreneurship in Sustainability Transitions: A Conceptual Synthesis against the Background of the Multi-Level Perspective", which was edited by Joseph Roberts, also deals with the role of one specific group of actors. Hörisch conceptually links different streams of literature on sustainability transitions and the multi-level perspective, sustainability transformations and on ecopreneurship, to analyse the role of sustainable entrerpeneurs in sustainability transitions. He concludes that sustainable entrepreneurs whose ventures produce positive externalities do not completely unfold their potential contribution to sustainable development, if they restrict their market effects to sustainability niches or limited user groups. Instead, for these particular actors, the contribution to sustainability transitions grows with the market impact of these ventures. Furthermore, based on the conceptual analysis, Hörisch suggests new insights to the multi-level perspective [8].

In her article on "The Rationality and Irrationality of Financing Green Start-Ups", Linda Bergset [9] also stresses the potential of green start-ups to contribute to sustainability transitions. Particularly, she emphasizes one specific challenge green entrepreneurs face, i.e., the challenge to finance green start-ups in the early stages of entrepreneurial venturing. In a first step, her paper explores the particularities of entrepreneurial finance in green start-ups when compared to conventional entrepreneurship. Second, based on a conceptual analysis drawing on entrepreneurial finance and behavioural finance, the author demonstrates the need for a more up-to-date conception of rationality in behavioural finance (and entrepreneurial finance).

\section{Outlook: Insights and Further Research Needs}

As section two highlights, the articles in this special issue are all connected to the potential contributions of sustainable entrepreneurship to sustainability transitions. This demonstrates that entrepreneurship indeed has the capability to facilitate sustainable development, if entrepreneurs follow the ideas of Schumpeter [1] as well as Hockerts and Wüstenhagen ([2], p. 482) and aim at transforming or even revolutionizing "a sector towards an environmentally and socially more sustainable state" through their entrepreneurial ventures. From an academic perspective, the articles' focus on sustainability transitions demonstrates a high need for platforms where research from the intersect between entrepreneurship and the nascent academic field of sustainability transitions can be discussed. Academics in entrepreneurship and business studies are thus challenged to create more platforms for research which goes beyond the boundaries of the firm, but investigates how entrepreneurial and corporate action can contribute to the solution of social and environmental problems.

Furthermore, it is remarkable that the contributions to this special issue focus on rather fundamental questions which have, however, so far received only scant attenention, such as the role of specific actor groups in sustainability transitions or the rationality in financing green start-ups. This suggests that, while more and more literature is dealing with sustainability in the context of entrepreneurship [10], a lot of rather fundamental questions have not yet sufficiently been adressed and that sustainable entrepreneurship as a research field is still emerging. From a methodological viewpoint, it is remarkable that this special issue as well as the field of sustainable entrepreneurship in general is characterised by a rather low number of quantitative analyses. As suggested by Edmondson and McManus [11] in the field of management studies, more quantitative research is needed in sustainable entrepreneurship to verify prior conceptual analysis.

More particlularly, the works included in this special issue highlight that conventional means of financing should be analysed based on the specific rationalility of financing green start-ups and that maybe even alternative means for financing sustainable start-ups which fit their specific rationality better should experience further research attention. In this context, crowdfunding for sustainable ventures experiences increasing attention, e.g., [12-14], but still a lot of aspects connected to the concept remain open for further investigations. Furthermore, the question how different actors can contribute to sustainability transitions is thematized in this special issue. Further research can build on the 
insights gained, e.g., by making use of case studies or quantitative analyses testing the conceptually derived roles of specific actor groups.

Acknowledgments: I would like to thank the authors who contributed to this special issue for their creative and thoughtful submissions. Furthermore, I am obliged to multiple reviewers, who dedicated their time for providing the authors with very valuable and constructive feedback.

Conflicts of Interest: The author declares no conflict of interest.

\section{References}

1. Schumpeter, J.A. Capitalism, Socialism \& Democracy; Routledge: London, UK, 1943.

2. Hockerts, K.; Wüstenhagen, R. Greening Goliaths versus emerging Davids-Theorizing about the role of incumbents and new entrants in sustainable entrepreneurship. J. Bus. Venturing 2010, 25, 481-492. [CrossRef]

3. Lumpkin, G.T.; Katz, J.A. Social and Sustainable Entrepreneurship; Emerald: Bingley, UK, 2011.

4. Belz, F.M.; Binder, J.K. Sustainable Entrepreneurship: A Convergent Process Model. Bus. Strat. Env. 2015. [CrossRef]

5. Hörisch, J.; Johnson, M.P.; Schaltegger, S. Implementation of Sustainability Management and Company Size: A Knowledge-Based View. Bus. Strat. Env. 2015, 24, 765-779. [CrossRef]

6. Augenstein, K.; Palzkill, A. The Dilemma of Incumbents in Sustainability Transitions: A Narrative Approach. Admin. Sci. 2016, 6, 1. [CrossRef]

7. Hörisch, J. The Role of Sustainable Entrepreneurship in Sustainability Transitions: A Conceptual Synthesis against the Background of the Multi-Level Perspective. Admin. Sci. 2015, 5, 286-300. [CrossRef]

8. Geels, F.W. The mulit-level perspective on sustainability transitions: Responses to seven criticisms. Environ. Innov. Soci. Trans. 2011, 1, 24-40. [CrossRef]

9. Bergset, L. The Rationality and Irrationality of Financing Green Start-Ups. Admin. Sci. 2015, 5, 260-285. [CrossRef]

10. Schaltegger, S.; Johnson, M.P. Sustainable Entrepreneurship: A Review; Leuphana University Lüneburg: Lüneburg, Germany, 2016.

11. Edmondson, A.; McManus, S.E. Methodological Fit in Management Field Research. Acad. Manage. Rev. 2007, 32, 1155-1179. [CrossRef]

12. Royal, C.; Windsor, G.S.S. Microfinance, Crowdfunding, and Sustainability: A Case Study of Telecenters in a South Asian Developing Country. Strategic Change 2014, 23, 425-438. [CrossRef]

13. Hörisch, J. Crowdfunding for environmental ventures: An empirical analysis of the influence of environmental orientation on the success of crowdfunding initiatives. J. Clean. Prod. 2015, 107, 636-645. [CrossRef]

14. Lam, P.T.I.; Law, A.O.K. Crowdfunding for renewable and sustainable energy projects: An exploratory case study approach. Renew. Sust. Energ. Rev. 2016, 60, 11-20. [CrossRef]

() 2016 by the author; licensee MDPI, Basel, Switzerland. This article is an open access article distributed under the terms and conditions of the Creative Commons by Attribution (CC-BY) license (http://creativecommons.org/licenses/by/4.0/). 